Strontium Concentrations in Chamisa

(Chrysothamnus nauseosus)

Shrub Plants Growing in a Former

Liquid Waste Disposal Area in Bayo Canyon

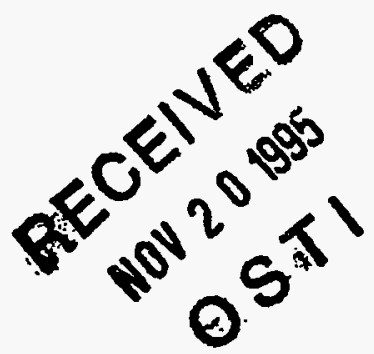


Edited by Hector Hinojosa, Group CIC-1

An Affirmative Action/Equal Opportunity Employer

This report was prepared as an account of work sponsored by an agency of the

United States Government. Neither The Regents of the University of Califormia, the United States Government nor any agency thereof, nor any of their employees, makes any warranty, express or implied, or assumes any legal liability or responsibility for the accuracy, completeness, or usefulness of any information, apparatus, product, or process disclosed, or represents that its use would not infringe privately owned rights. Reference herein to any specific commercial product, process, or service by trade name, trademark, manufacturer, or otherwise, does not necessarily constitute or imply its endorsement, recommendation, or favoring by The Regents of the University of California, the United States Government, or any agency thereof. The views and opinions of authors expressed herein do not necessarily state or reflect those of The Regents of the University of California, the United States Government, or any agency thereof. The Los Alamos National Laboratory strongly supports academic freedom and a researcher's right to publish; therefore, the Laboratory as an institution does not endorse the viewpoint of a publication or guarantee its technical correctness. 
Strontium Concentrations in Chamisa

(Chrysothamnus nauseosus)

Shrub Plants Growing in a Former

Liquid Waste Disposal Area in Bayo Canyon

P. R. Fresquez

T. S. Foxx

L. Naranjo, Jr. 


\section{DISCLAIMER}

Portions of this document may be illegible in electronic image products. Images are produced from the best available original document. 


\title{
STRONTIUM CONCENTRATIONS IN CHAMISA (Chrysothamnus nauseosus) SHRUB PLANTS GROWING IN A FORMER LIQUID WASTE DISPOSAL AREA IN BAYO CANYON
}

by

\author{
P.R. Fresquez, T.S. Foxx, and L. Naranjo Jr.
}

\begin{abstract}
Chamisa (Chrysothamnus nauseosus) shrub plants growing in a former liquid waste disposal site (Solid Waste Management Unit [SWMU] 10-003[c]) in Bayo Canyon at Los Alamos National Laboratory (LANL) were collected and analyzed for strontium (90Sr) and total uranium. Surface soil samples were also collected from below (understory) and between (interspace) shrub canopies. Both chamisa plants growing over SWMU 10-003(c) contained significantly higher concentrations of ${ }^{90} \mathrm{Sr}$ than a control plant-one plant, in particular, contained $90,500 \mathrm{pCi}^{90} \mathrm{Sr} \mathrm{g}^{-1}$ ash in top-growth material. Similarly, soil surface samples collected underneath and between plants contained ${ }^{90} \mathrm{Sr}$ concentrations above background and LANL screening action levels; this probably occurred as a result of chamisa plant leaf fall contaminating the soil understory area followed by water and/or winds moving ${ }^{90} \mathrm{Sr}$ to the soil interspace area. Although some soil surface migration of ${ }^{90} \mathrm{Sr}$ from SWMU 10-003(c) has occurred, the level of $90 \mathrm{Sr}$ in sediments collected downstream of SWMU 10-003(c) at the Bayo Canyon/State Road 4 intersection was still within regional (background) concentrations.
\end{abstract}

\section{INTRODUCTION}

Several studies have shown that vegetation growing over buried low-level radioactive waste sites at Los Alamos National Laboratory (LANL) may translocate radionuclides from the roots to aboveground plant compartments (Dreesen and Marple 1980, Wenzel et al. 1987, Fresquez et al. 1995a). Deep-rooted perennial plant species like trees and shrubs were cited to be the major offenders (Foxx et al. 1984a, Foxx et al. 1984b), and may act as conduits to other biotic (Hakonson and Bostick 1976, Gilbert et al. 1988, Pinder et al. 1991) and abiotic (Healy 1977, Lee et al. 1985, Becker 1992, Bunzl et al. 1994) components that may eventually result in a radiation dose to humans (Fresquez et al. 1994, Fresquez et al. 1995b, Fresquez et al. 1995c, Fresquez et al. 1995d).

During a recent Environmental Restoration predrilling radiological surface survey in Bayo Canyon at LANL, some Chamisa (Chrysothamnus nauseosus) shrub plants exhibited elevated beta radioactivity (Derek Faulk, ERM/Golder, personal 
communication, July 1994) (Figure 1). These late-successional plants, which may root as deep as $4.5 \mathrm{~m}$ (13.5 ft) (Tierney and Foxx 1987), were growing over a former liquid waste disposal structure (\#TA-10-43) (Solid Waste Management Unit [SWMU] 10003[c]) (LANL 1992). Liquid waste disposal structure TA-10-43 held lanthanum (140La) and strontium $\left({ }^{90} \mathrm{Sr}\right)$ contaminated wastes generated by the radiochemistry laboratory (TA-10-1) and was decommissioned and decontaminated in 1963-the structure was removed, excavated to a depth of $6 \mathrm{~m}(18 \mathrm{ft})$, and backfilled with soil and building debris from other parts of the TA-10 operation (Blackwell and Babich 1963). In 1974, a soil subsurface investigation detected elevated levels of gross beta radioactivity near SWMU 10-003(c) (Mayfield et al. 1979).

Strontium-90, a beta emitting isotope with a relatively long half-life (28 years) and high degree of food chain mobility, constitutes a potential long-term hazard (Wicker and Schultz 1982). The objective of this study was to determine the amount of ${ }^{90} \mathrm{Sr}$ uptake in deep-rooting chamisa plants from a former liquid waste disposal area and determine the extent of soil-surface contamination.

\section{METHODS}

Soil samples were collected underneath (understory) and between (interspace) two chamisa plant shrub canopies-those that measured the highest in beta radioactivity with field survey instrumentation-growing in Bayo Canyon with a stainless steel scoop at the 0- to 2-inch depth in August of 1994. At least three subsamples were collected from each zone, mixed thoroughly in a stainless steel bowl, poured into $500-\mathrm{mL}$ poly bottles, and double bagged in Ziploc containers. Similarly, plant top growth and root

growth from each of the two chamisa plants were sampled by cutting the desired plant parts into 1- to 2-inch pieces, placing into 1-L glass beakers, covering with tin foil, and double bagging into Ziploc containers. All samples were transported to the Laboratory under full chain-of-custody protocols in a locked ice chest. At the Laboratory, plant samples were ashed to $500^{\circ} \mathrm{C}$, transferred to labeled $500-\mathrm{mL}$ poly bottles, sealed with chain-of-custody tape, and submitted along with the soil samples to the Environmental Chemistry Group for the analysis of ${ }^{90} \mathrm{Sr}$ using a gas-proportional counter technique (Purtyman et al. 1987) and total uranium by the kinetic phosphorescence method (Fresquez et al. 1995).

\section{RESULTS}

The analysis of ${ }^{90} \mathrm{Sr}$ and total uranium in chamisa plants and soils collected over SWMU 10-003 (c) in Bayo Canyon can be found in Table 1 and Table 2, respectively. 


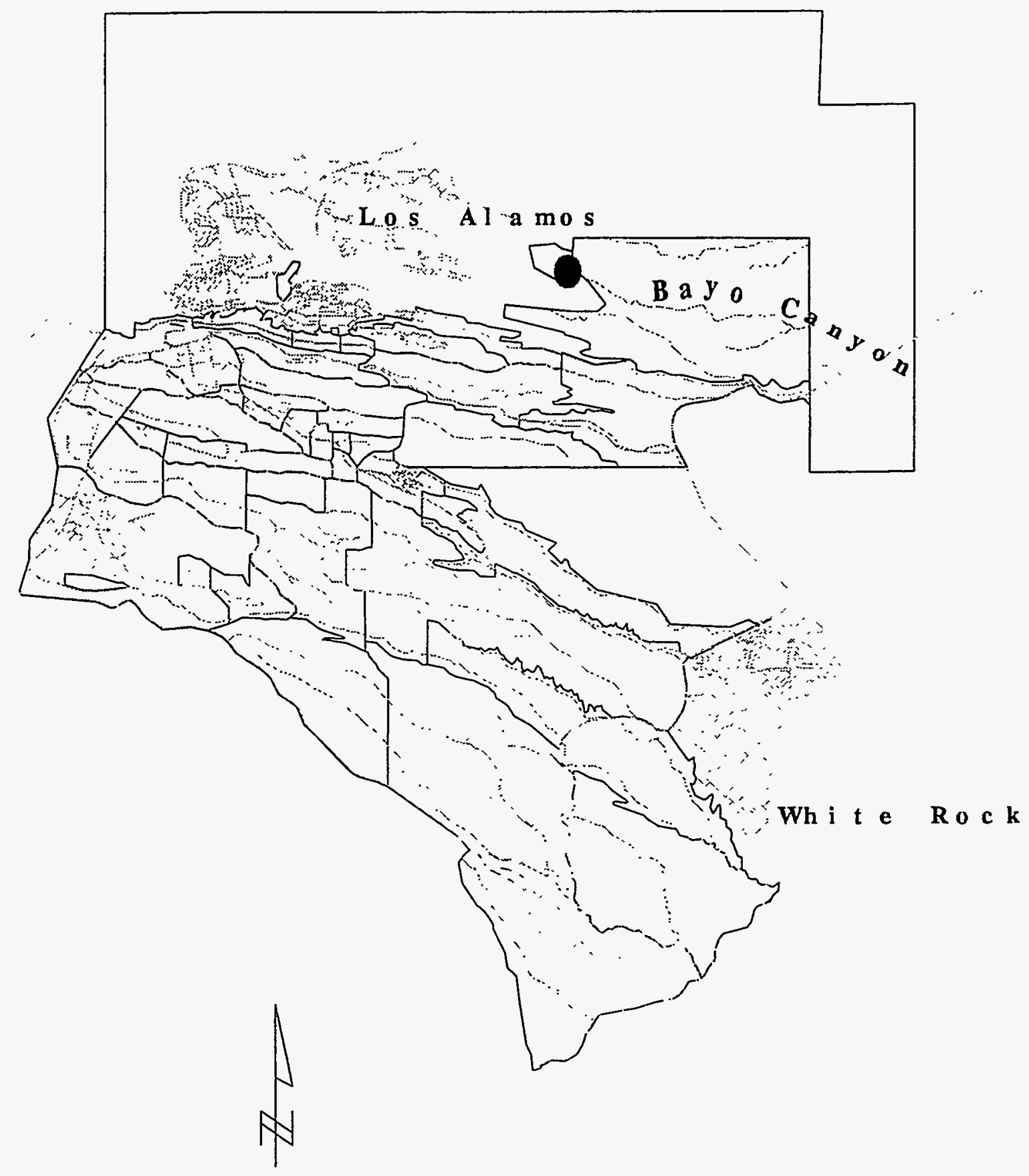

Figure 1. Sample Locat i n within

B a yo Can yon a $t$

Los Alamos National Laborat ory 


\begin{tabular}{|c|c|c|c|c|}
\hline Sample & \multicolumn{2}{|c|}{${ }^{90} \mathrm{Sr}\left(\mathrm{pCi} \mathrm{g}^{-1} \mathrm{ash}\right)$} & \multicolumn{2}{|c|}{ Total U ( $\mu \mathrm{g} \mathrm{g}^{-1}$ ash) } \\
\hline \multicolumn{5}{|c|}{ Chamisa SWMU Plant 1} \\
\hline top growth & $90,500.00$ & $(11,140.00)^{3}$ & 0.67 & $(0.02)$ \\
\hline root growth & $40,600.00$ & $(5,000.00)$ & 3.12 & $(0.62)$ \\
\hline \multicolumn{5}{|c|}{ Chamisa SWMU Plant 2} \\
\hline top growth & $5,930.00$ & $(740.00)$ & 0.73 & $(0.02)$ \\
\hline root growth & $4,630.00$ & $(580.00)$ & 3.19 & $(0.64)$ \\
\hline \multicolumn{5}{|c|}{ Chamisa Background Plant } \\
\hline top growth & 0.30 & $(0.40)$ & 0.78 & $(0.16)$ \\
\hline root growth & 0.00 & $(0.20)$ & 3.15 & $(0.64)$ \\
\hline \multicolumn{5}{|c|}{$\begin{array}{l} \pm 2 \text { counting uncertainty); values are the uncertainty in the analytical result at the } \\
95 \% \text { confidence level. } \\
\text { Collected } 0.82 \mathrm{~km} \text { east of plants } 1 \text { and } 2\end{array}$} \\
\hline
\end{tabular}

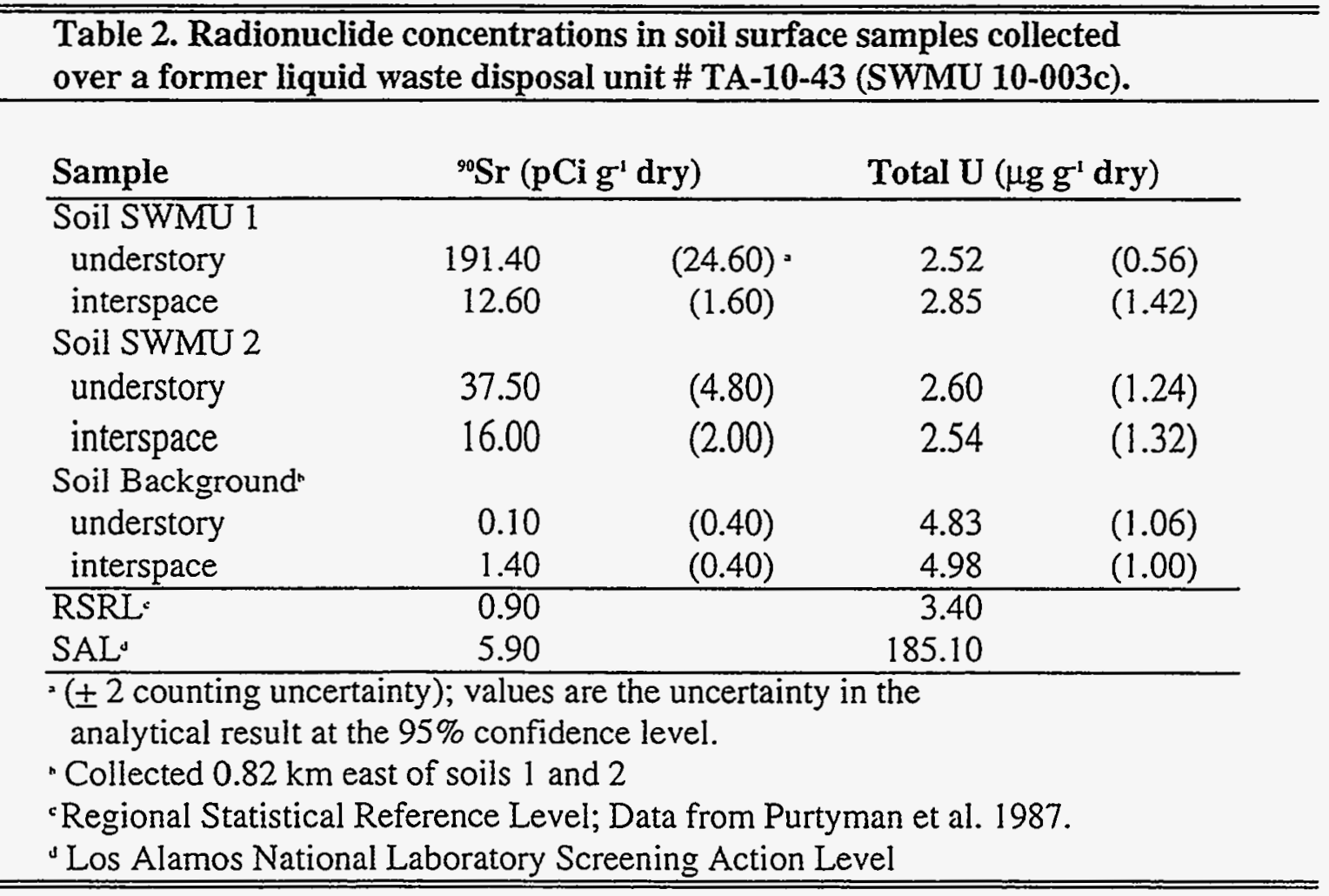


Both chamisa plants, and especially in top-growth material, contained significantly higher concentrations of ${ }^{90} \mathrm{Sr}$ than top-growth material collected from a background chamisa plant. One chamisa plant, in fact, contained $90,500 \mathrm{pCi} \mathrm{g}^{-1}$ ash of ${ }^{90} \mathrm{Sr}$ - over 300,000 times higher than the control plant. Although the amount of ${ }^{90} \mathrm{Sr}$ contamination at depth (source) is not completely known, a recent Environmental Restoration borehole investigation conducted approximately 2 to 3 feet away from where the plants where collected showed 4,201 $\mathrm{pCi} \mathrm{g}^{-1}$ of ${ }^{90} \mathrm{Sr}$ at the $5-(15-\mathrm{ft})$ to $5.3-\mathrm{m}(16-\mathrm{ft})$ depth (Newlin 1995). Strontium-90, a high biological mobile isotope because of its chemical similarity to calcium, is readily taken up by plants (Menzel 1965) and chamisa plant roots have been shown to grow as deep as $4.5 \mathrm{~m}$ (13.5 ft) or more (Tierney and Foxx 1987). All uranium levels in top-growth and root-growth materials from chamisa plants growing over SWMU 10-003(c) were equal to uranium levels in top-growth and root-growth samples from chamisa plants collected from a background location. The higher concentrations of uranium in the roots of the chamisa plants as compared to the top-growth materials were probably due to the fact that the root samples contain more soil on the surface than does the top-growth material which biased the analytical results.

Both understory and interspace soil samples contained ${ }^{90} \mathrm{Sr}$ at above-background concentrations; this probably occurred as a result of chamisa plant leaf fall contaminating the soil understory area followed by water and/or wind dispersal contaminating the soil interspace areas. Soil collected from underneath chamisa plant \#1, in fact, contained 1,914 times more ${ }^{90} \mathrm{Sr}$ than background soil samples which correlates very well with the chamisa plant uptake data. Interspace soil areas also contained ${ }^{90} \mathrm{Sr}$ at elevated levels ranging in concentration from 13 to $16 \mathrm{pCi} \mathrm{g}^{-1}$; the highest level was over 11 times higher than background. Moreover, both understory and interspace soil areas contained ${ }^{90} \mathrm{Sr}$ levels above the LANL screening action level (SAL) of $5.9 \mathrm{pCi} \mathrm{g}^{-1}$ (Dorries 1994). Radionuclide concentrations in soils above SAL's, which are based on radiation dose levels using a risk assessment pathway computer code called RESRAD, initiate and require the Laboratory to further evaluate the area (i.e., site-specific baseline risk assessment, additional sampling, etc.) (ERAC 1995). Although the soils data show that some migration of ${ }^{90} \mathrm{Sr}$ from the contaminated source has occurred, the levels of ${ }^{90} \mathrm{Sr}$ in sediments $\left(0.10 \mathrm{pCi}^{-1}\right)$ collected downstream of SWMU 10-003(c) at the Bayo Canyon/State Road 4 intersection in 1994 (EPG 1995) were still within regional (background) concentrations ( $0.87 \mathrm{pCi} \mathrm{g}^{-1}$ ) (Purtymun et al. 1987), however. Also, all uranium concentrations in soils collected from underneath and between chamisa plants growing over SWMU 10-003(c) were witbin background soil concentrations. These data correlated very well with other soil uranium background studies conducted within LANL 
(Longmire et al. 1995) and regional off-site areas (Fresquez et al. 1995).

\section{ACKNOWLEDGMENT}

We would like to thank John Salazar and Dale Lyons for helping with sample collection and processing. Also, thanks to Joy Ferenbaugh (graduate research assistant) and Stephanie White (undergraduate student) for tabulating the data, Mary Salisbury for constructing the figure, and to Gary Allen (CST-18) and Derek Faulk (ERM/Golder) for providing site access, RFI information, and manuscript review.

\section{REFERENCES}

Becker, N.M., "Quantification of Uranium Transport Away From Firing Sites at Los Alamos National Laboratory-A Mass Balance Approach," in Proceedings of the Symposium on Waste Management: Technology and Programs for Radioactive Waste Management and Environmental Restoration, R.G. Post, Ed., Tucson, Arizona (March 1-5, 1992).

Blackwell, C.D. and F. Babich, "Removal of all Structures in Bayo Canyon," Los Alamos Scientific Laboratory memorandum, Environmental Restoration Records Processing Facility I.D.\# 2070 (1963).

Bunzl, K., H. Forster, W. Kracke, and W. Schimmack, "Residence Times of Fallout

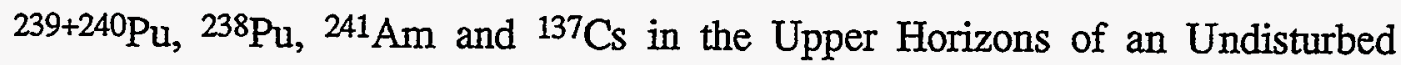
Grassland Soil," Journal of Environmental Radioactivity, 22:11-27 (1994).

Dreesen, D.R. and M.L. Marple, "Uptake of Trace Elements and Radionuclides From Uranium Mill Tailings by Fourwing Saltbush (Atriplex canescens) and Alkali Sacaton (Sporobolus airoides)," Los Alamos Scientific Laboratory report LAUR-79-3045 (March 1980).

Dorries, A., "July 1994 Screening Action Levels," Los Alamos National Laboratory memorandum EM/ER:94-S390 (July 1994).

EPG, "Environmental Surveillance at Los Alamos During 1994," Environmental Protection Group, Los Alamos National Laboratory report LA-12973-ENV (In Press 1995).

ERAC, "Screening Assessment Methodology at Los Alamos National Laboratory," Environmental Restoration Assessments Council, Los Alamos National Laboratory policy paper (In Press 1995).

Foxx, T.S., G.D. Tierney, and J.M. Williams, "Rooting Depths of Plants on Low-Level Waste Disposal Sites," Los Alamos National Laboratory report LA-10253-MS (October 1984a). 
Foxx, T.S., G.D., Tierney, and J.M. Williams, "Rooting Depths of Plants to Biological and Environmental Factors," Los Alamos National Laboratory report LA-10254MS (November 1984b).

Fresquez, P.R., D.R. Armstrong, and J.G. Salazar, "Radionuclide Concentrations in Game and Nongame Fish Upstream and Downstream of Los Alamos National Laboratory: 1981 to 1993," Los Alamos National Laboratory report LA-12818MS (August 1994).

Fresquez, P.R., J.B. Biggs, and K.D. Bennett, "Radionuclide Concentrations in Vegetation at Radioactive-Waste Disposal Area G during the 1994 Growing Season," Los Alamos National Laboratory report LA-12954-MS (June 1995a).

Fresquez, P.R., D.R. Armstrong, and J.G. Salazar, "Tritium Concentrations in Bees and Honey at Los Alamos National Laboratory," Los Alamos National Laboratory report LA-12872-MS (May 1995b).

Fresquez, P.R., D.R. Armstrong, and J.G. Salazar, "Radionuclide Concentrations in Elk That Winter on Los Alamos National Laboratory Lands," Los Alamos National Laboratory report LA-12795-MS (January 1995c).

Fresquez, P.R., D.R. Armstrong, and J.G. Salazar, "Radionuclide Concentrations in Soils and Produce from Cochiti, Jemez, Taos, and San Ildefonso Pueblo Gardens," Los Alamos National Laboratory report LA-12932-MS (May 1995d).

Fresquez, P.R., M.A. Mullen, and J.K. Ferenbaugh, "Radionuclides and Radioactivity in Soils Within and Around Los Alamos National Laboratory: 1974 to 1994," Los Alamos National Laboratory report LA-UR-95-3671 (November 1995).

Gilbert, R.O., J.H. Shinn, E.H. Essington, T. Tamura, E.M. Romney, K.S. Moor, and T.P. O'Farrel, "Radionuclide Transport from Soil to Air, Native Vegetation, Kangaroo Rats and Grazing Cattle on the Nevada Test Site," Health Physics, 55:869-887 (1988).

Hakonson, T.E., and K.V. Bostick, "The Availability of Environmental Radioactivity to Honeybee Colonies at Los Alamos," Journal of Environmental Quality, 5:307-310 (1976).

Healy, J.W., "An examination of the Pathways from Soil to Man for Plutonium," Los Alamos Scientific Laboratory report LA-6741-MS (April 1977).

LANL, "RFI Workplan for Operable Unit 1079;" Los Alamos National Laboratory report LA-UR-92-850, (May 1992).

Lee, S.Y., T. Tamura, and E.H. Essington, "Characteristics of Radioactivity Contamination of Soil at the Nevada Test Site," Nuclear and Chemical Waste Management, 7:179-190 (1985). 
Longmire, P., S. Reneau, P. Watt, J. Garner, C. Duffy, and R. Ryti, "Natural Background Geochemistry, Geomorphology, and Pediogenisis of Selected Soil Profiles and Bandelier Tuff, Los Alamos, New Mexico," Los Alamos National Laboratory report LA-12913-MS (1995).

Mayfield, D.L., A.K. Stoker, and A.J. Ahlquist, "Radiological Survey of the Bayo Canyon, Los Alamos, New Mexico," Department of Energy report DOE/EV0005/15 (1979).

Menzel, R.G., "Soil-Plant Relationships of Radioactive Elements," Health Physics, 11:1325-1332 (1965).

Newlin, J., "Strontium-90 Data From OU 1079 Bayo Canyon Boreholes," Los Alamos National Laboratory memorandum CST-ER/JN-95/01 (1995).

Pinder, J.E., K.W. McLeod, R.F. Lide, and K.C. Sherrod, "Mass Loading of Soil Particles on a Pasture Grass," Journal of Environmental Radioactivity, 13:341-354 (1991).

Purtymun, W.D., R.J. Peters, T.E. Buhl, M.N. Maes, and F.H. Brown, "Background Concentrations of Radionuclide in Soils and River Sediments in Northern New Mexico, 1974-1986," Los Alamos National Laboratory report LA-1134-MS (1987).

Tierney, G.D., and T.S. Foxx, "Root Lengths of Plants on Los Alamos National Laboratory Lands," Los Alamos National Laboratory report LA-10865-MS (January 1987).

Wicker, W.F., and V. Schultz, Radioecology: Nuclear Energy and the Environment, CRC Press, Inc., Boca Raton, FL. (1982).

Wenzel, W.J., T.S. Foxx, A.F. Gallegos, G. Tierney, and J.C. Rogers, "Cesium-137, Plutonium-239/240, Total Uranium, and Scandium in Trees and Shrubs Growing in Transuranic Waste at Area G," Los Alamos National Laboratory report LA11126-MS (November 1987). 